\title{
Family political socialisation and its effect on youth trust in government: a South African perspective
}

\author{
Michelle Vera Esau, Carol Hilary Rondganger and Nicolette Vanessa Roman
}

\begin{abstract}
Current debates on citizenship and democracy highlight the salience of cooperative relations between government and its citizens. Scholars observe that governments and its institutions function better where there is cooperation and trust. However, evidence suggests that political interest is waning and trust in government, dwindling. More especially, concerns about the effects of youth disengaging from political life are increasing. This phenomenon is more worrying in young democracies, where democratic traditions and principles are still evolving. This study examines the effect of family politicisation on youth trust in government. This quantitative study used a cross-sectional correlational research design. A two-level approach was adopted. At the first level we examined the prevalence of political discussions in the home and the trust attitudes of the family (as indicators of family politicisation) and youth towards government. At a second level we conducted a regression analysis to determine relationships between parent-adolescent communication and youth trust in government; family trust in government and youth trust in government; and finally, parent-adolescent communication and family trust on youth trust in government. The results suggest that a combination of parent-adolescent communication and family trust in government in a model, significantly positively predicts youth trust in government.
\end{abstract}

\section{Introduction}

Current debates on citizenship and democracy illustrate the centrality of cooperative relations between ordinary citizens and the state in creating effective and efficient public institutions. Much of these debates are premised on the earlier work of Robert Putnam (1993) that elevates the effects of social capital and trust on institutional performance. Putnam (1993) observes, through the case of the introduction of regionalism in Italy, how democracies function better when there is cooperation and trust. Others have also emphasised the link between cooperation and trust on the ideal-type democracy (Sztompka 1999; Schoon and Cheng 2011). Worldwide however, studies suggest that citizens' interest in politics is on the decline and that trust in public institutions is dwindling (Jamil and Askvik 2016; Stoker 2017). Moreover, and with the growing realisation that youth participation in politics is central to the survival of democracy (Mattes and Richmond 2014; Zeldin et al. 2017), the trend of distrust and political disinterest emerging amongst the youth (Crystal and DeBell 2002; Bessant 2004; Lee, 
Shah, and McLeod 2012) is disconcerting. Since effectively functioning democratic institutions are dependent on cooperation between government and citizens, citizen disengagement from formal participatory state processes can affect the nature of policies, laws and ultimately government's responsiveness to the needs of its citizens. Moreover, disaffected attitudes and behaviours of the youth could potentially threaten the formal traditions and notions of democracy.

Given the above, the socialisation of the youth to politics emerges as an area of scholarly interest, especially in the context of emerging democracies. Questions that focus on the agencies of socialisation and how these agencies influence the political attitudes and behaviours of the youth are considered significant to the effectiveness of the socialisation process. Quintessentially, the construct of political socialisation highlights the effect of various agencies within the environment of the young child on his/her political attitudes and behaviours later in life. On the one hand, these agencies serve to transfer values, knowledge and norms that contribute to the maintenance of a political system (Easton 1957). On the other hand, agencies of socialisation contribute to the development of an individual's competencies and skills that enable meaningful engagement between that individual and the political system (Lee, Shah, and McLeod 2012). To this end, communication about politics between an individual and socialising agents is identified as central to the transfer of knowledge, values, norms and competencies that nurture and develop active citizenship post-childhood.

The family is considered the first agency of socialisation for the young child to politics (Easton 1957; King and Merelman 1986; Gelles 1995). More specifically, evidence suggests that the social interaction of parent-child communication contributes to how the young person constructs knowledge of and attributes importance to the political world (McIntosh, Hart, and Youniss 2007, 497). In addition, political discussions in the family combined with parents' political activism (participating in volunteering, demonstrations or voting) are shown to be stronger predictors of future youth active citizenship, than parent-adolescent communication in and of itself (Andolina et al. 2003; Esau and Roman 2015). Regardless however, of the different forms of socialisation and its effect on the attitudes and behaviours of the child, at a basic level parent-adolescent communication is considered important for initiating political interest in the early stages of a child's life.

Against this background, a study examining what is happening within the family insofar as the political socialisation of the youth is concerned is relevant. With attention largely devoted to the case of political socialisation of the youth in industrialised democracies, little is known about the effects of the family on the political socialisation of the youth in young democracies in general, and South Africa in particular. Much of the attention on the political socialisation of the youth in South Africa for example, has been focused on the general conceptions of youth about their citizenship (Mattes and Richmond 2014), the influence of post-conflict communities on the socialisation of youth (Errante 1999) and the role of the schooling system in the civic education of the youth (Finkel and Ernst 2005). In addition, evidence suggests that while the family is an important agency for the transmission of democratic 
values and norms within industrialised or stable democracies, the same may not be true in the case of younger or less stable democracies (Torney-Purta, Barber, and Richardson 2004). Therefore, a study focused on the role played by the family in the politicisation of the youth, from a South African perspective, may enrich our knowledge of the effects of the family on the politicisation of the youth in young democracies.

The aim of this article is to examine the effect of parent-adolescent communication and family trust in government on youth trust in government. To this end, we adopt a twolevel approach. At the first level, we examine the prevalence of political discussions in the home. We also gauge the attitudes of family trust and youth trust in government. At the second level, we examine the relationships between parent-adolescent communication (as an indicator of political discussions in the family) and youth trust in government; family trust in government and youth trust in government, and finally parent-adolescent communication and family trust on youth trust in government by conducting a regression analysis to determine which of the variables predict youth trust in government.

\section{A theoretical context for examining the agency of family}

Easton's system maintenance theory and Bronfenbrenner's ecological systems theory are two relevant and interrelated theories that provide a useful context through which to examine the role of the family on the political development of the child. Both theories position the microenvironment of the family as important to the child's learning about, and interacting with, the social and/or political environments, albeit grounded within different disciplines. Moreover, the theories position the family as one of the agencies fundamental to facilitating a relationship between the child and structures external to the latter's immediate environment. In the case of Easton's system maintenance theory, the family is viewed as an agent of socialisation through its transmission of knowledge, values, attitudes and norms (Easton and Dennis 1965, 41). In fact, according to Easton and Dennis $(1965,41)$ 'without socialization across the generations, each new member of the system, whether a child newly born into it or an immigrant newly arrived, would have to seek an entirely fresh adjustment in the political sphere'. Easton's theory conceives of politicisation in the context of an input-process-output model. He places the interrelations between the political system and its environment at the centre of this model, where demands and support are considered the inputs that stimulate members' political interest and activity (Easton 1957, 384) and energise the political system. In particular it shows how, through the processing of inputs into outputs, members of the political system and/or ordinary citizens are able to influence the nature of laws, policies and decisions through their participation and engagement in state structures and processes. Where citizens' interests, demands and needs are met as evidenced through the outputs, a cycle of support for the system is perpetuated. However, where members and/or citizens' needs are not met, the survival of the system may be in jeopardy. Therefore, demands as inputs into the model on the one hand, and responsiveness of government to these demands, on the other, are key to energizing the interrelations between the political system and members in its environment. 
Similarly, through the process of politicisation support for a political system is generated. In Easton's (1957) view, politicisation refers to a steady process of manufacturing support for a political system. Manufacturing support encompasses a number of behaviours that include, discussing politics, engaging in political activities and cooperating with government through its formal institutions, structures and processes (as illustrated above). Accordingly, support may encompass both observable external acts that include voting for a particular political party and internal forms of behaviour, called orientations or states of mind (Easton 1957, 390). To this end, it is argued that individuals learn what is acceptable and what is not from their parents, family and other members of society who are entrusted with communicating and imparting political values, norms and beliefs (Easton 1957). In this context, the attitudes and behaviours emerging out of the family environment are pertinent to how 'a person learns to play his various social roles' (Easton 1957, 397). In the absence of this kind of social interaction and relationship, the quality of a political system or the survival of that system in general, may be at risk of extinction.

Bronfenbrenner's multi-layered ecological system to human development is another theoretical framework that helps us to understand the role of the family in the political development of the child. It is important to emphasise that we use the early version of Bronfenbrenner's theory that emphasises environmental levels and the proximal processes that occur at these levels in nurturing interrelations between the child and the political system. Like Easton, Bronfenbrenner identifies the family as one of the important agencies to the cognitive and behavioural development of the child. He postulates that human development is influenced by processes of reciprocal interaction (that become more complex with time) between an 'active and evolving bio-psychological human organism and the persons, objects and symbols in its immediate environment' (Bronfenbrenner 1999, 5). In addition, he observes that, for the interaction to be effective, it needs to occur fairly regularly over extensive periods of time. Bronfenbrenner $(1995,5)$ describes these kinds of interactions as proximal processes that are found in parent-child and child- child activities, group or solitary play, reading and studying, and so on. Proximal processes however are influenced by peculiarities within the immediate environment of the child. Therefore, variables such as socio-economic status, race and gender, etc., may influence how interactive processes impact the development of the child. Bronfenbrenner $(1995,625)$ uses the example of children in poor environments and the impact of proximal processes on their dysfunctionality. On the contrary, stable environments are shown to contribute to developmental competence evidenced through academic achievement, cognitive abilities and social skills (Bronfenbrenner 1995, 625). While the effect of the socio-economic environment on the child's development is not our specific focus, we observe that the social interaction demonstrated through, in this instance, political discussions between the parent and the child, is important in shaping the political attitudes of the child.

Secondly, Bronfenbrenner emphasises the effect of the interrelations between various layers in the environment on the child's development. He distinguishes between five layers that include the microsystem, mesosystem, exosystem, macrosystem and chronosystem. Of 
particular interest to our study is the interaction between the micro and exosystems. The microsystem refers to the environment wherein the child primarily functions and lives and has a direct effect on the behaviour, attitude and general development of the child. The family, school and community are considered part of the microsystem and it is within this system that interrelations between the child and 'the other' are considered significant insofar as the attitudes and beliefs of the child, in later years, are concerned. Bronfenbrenner (cited in Paquette and Ryan 2011) refers to the interactions within an environment and between environments as having both a direct and indirect effect on the child's development. However, the interactions within the microsystem are considered most significant in terms of influencing the child's attitudes and behaviours towards individuals, structures, institutions and processes in other environments (Paquette and Ryan 2011). The exosystem, on the other hand, refers to structures and factors outside of the immediate environment of the child. However, the activities within the exosystem can have a direct and/or indirect influence on the child. Bronfenbrenner (1994) provides the example of a working mother who experiences stress in her work environment (the exosystem). The work-related stress may have an indirect influence on the child through his/her mother's behaviour when in the home environment (the microsystem). Similarly, and in the context of the interrelations between the political system, on the one hand, and the family on the other, the decisions emerging from these interrelations or through the political system, may have a direct or indirect influence on the child. For example, the enactment of policies and laws that pertain to education and/or child grants, for example, will have a direct effect on the child. In the case of attitudes of the family towards state institutions and processes, the effect may be indirect in the shorter term, but more direct post-childhood when the individual starts to exercise his/ her rights of citizenship.

Sound theoretical frameworks provide a disciplinary and interdisciplinary platform through which to examine and understand specific phenomenon in similar and/or different social, political and economic contexts, regardless of the passing of time. Therefore, the choice of Easton's system maintenance theory and Bronfenbrenner's ecological development approach, albeit dating back to the mid-twentieth century and informed by different disciplinary contexts, allows for the examination and understanding of the agency of family on the interrelationship between the child and the political system. More especially, Easton's system maintenance theory facilitates our perspective that the family has a role to play in maintaining the political system (in the case of well performing and responsive governments) through the transmission of political values, norms and attitudes. On the other hand, Bronfenbrenner's ecological development approach provides insights into the nature of the family environment and how what is being discussed in the home may influence the attitudes of the youth towards government. These perspectives facilitate our examination of how family politicisation influences the trust attitudes of the youth towards government.

\section{The political socialisation influences of the family}

Socialisation is defined as 'the process whereby one acquires a sense of personal identity and learns what people in the surrounding culture believe and how they expect one to 
behave ...' Gelles (as cited in Esau and Roman 2015, 42). Similarly, political socialisation can be defined as the process of learning of political attitudes, values and beliefs that could potentially influence an individual's attitudes and behaviours towards politics and political activities in the future. This 'political learning' occurs through various agencies at different levels and/or within the different environments of the child (Niemi and Sobieszek 1977; Watts and Flanagan 2007; Jennings, Kent, and Bowers 2009). The different agencies of political socialisation and its effects on the political attitudes of the young child towards government in the future has been the centre of scholarly interest for several decades (Easton 1957; Hyman 1959; Beck and Kent Jennings 1991; Amna et al. 2009; Quintelier 2013 and 2015; Russo and Amna 2016; Kristensen and Solhaug 2017).

In general and with reference to family politicisation, the debate broadly distinguishes between two perspectives on political socialisation. In the first instance, the child is viewed as a passive recipient in his/her political development. To this end, the child receives knowledge and skills from the parents/family in a unidirectional manner that results in the transmission of the parents/family political views and beliefs. In this regard, Beck and Kent Jennings (1991, 745-746) refer to a politicised family environment as one where the child observes the parents attention to political matters, such as voting in elections, participating in community meetings and frequent engagement in political affairs. Moreover, political discussions between family members essentially occur with the intention to influence other family members' political orientations.

Beck and Kent Jennings (1991) succinctly capture the effects of family politicisation by observing as follows: 'the accident of birth places the individual into a particular family environment, which nurtures political (or apolitical) outlooks early in life and locates the individual in a socio-political setting that may last a lifetime' (742-743).

More recent research on family politicisation however, views the child as an active player in his/her political development (Amna et al. 2009; Kallio 2014; 2017; Kristensen and Solhaug 2017). This perspective conceives of the family environment as a space that not only nurtures political interest, but also one that contributes to the "political becoming' (Kallio 2014) of the child. In this instance, the conversations and activities that occur within the family environment allows for bi-directional engagement that encourages both the political volition of the child and political self-reflection post-childhood (Kristensen and Solhaug 2017; Kallio 2017). This perspective deviates from earlier studies that focused on political socialisation as the importation of political values, beliefs and attitudes from one generation to the next. The political self-reflection or 'political becoming' (Kallio 2017) perspective regards the family environment as an important agency that nurtures not only political interest, but also enables self-reflection and political identity later in life (Kristensen and Solhaug 2017).

Regardless of the perspective adopted, evidence suggests that the family environment can influence the attitudes of the child towards politics. Beck and Kent Jennings (1991) refer to the long-term effects of the political attitudes, views and behaviours of the family on 
the life span of the adult. Similarly, the study by Jennings, Kent, and Bowers (2009, 795) on the effects of intergenerational transmission and early political socialisation on attitude formation, find that parents who are politically engaged, frequently discuss politics with their children and are consistent in their political cue-giving have a significant effect on the political learning that happens in pre-adulthood. In addition, their study shows that children who are politicised by their parents earlier in life are more likely to maintain their parents' political predispositions (Jennings, Kent, and Bowers 2009, 796), values and attitudes. Verba, Scholzman, and Brady (1995) also observe that individuals growing up in homes where parents frequently discussed politics and engaged in political activities were more likely to become involved in political activities later in life than individuals who grew up in homes where this kind of socialisation did not happen. More recent work also refers to the effect of the family on the civic and political engagement of the youth through the parents' interest in political and social issues, civic volunteering, etc. (Coffe and Voorpostel 2010; Cicognani et al. 2012; Dinas 2014). For example, Dinas (2014, 828) observes that parents who exhibit high levels of political engagement will be more successful in transmitting political interest to their children. Through their active engagement, parents deepen the pre-adult learning of their children, which results in the transmission of political attitudes from parent to child (Dinas 2014, 829). Moreover, children from politicised family environments are more likely to become politically engaged adults who develop their own identity and voice based on their personal political experiences later in life, than those who come from less politicised family environments. Hampton, Shin and $\mathrm{Lu}$ (2017) also refer to the context of politicisation, but from the perspective of political deliberation. They consider deliberation (political discussion, conversation, talk, etc.) as fundamental to democratic processes. In their view deliberation, whether in public or private spaces such as the home environment, can influence political attitudes, levels of generalised trust, civic engagement and political participation (Hampton, Shin and Lu 2017).

Basically, the evidence suggest that parents, through the process of politicisation, be it talking about politics, being involved in political activities or through civic engagement, transmit cues to their children that have the potential to influence the latter's political beliefs and attitudes, be it similar or different to those of their parents (Verba, Scholzman, and Brady 1995; Jennings, Kent, and Bowers 2009; Quintelier 2015; Kallio 2017). It is this perspective that stimulates our initial interest in whether families in young democracies are talking about politics to their children, and whether these discussions have an effect on the trust attitudes of the child towards government, given the concerns expressed earlier.

\section{The family and communication of trust cues}

The above highlights the effect of political discussions within the family environment on the development of the political orientations of the child. Equally important is the nature or the content of these conversations on the child's political attitudes and behaviours (Saphir and Chaffee 2002; Rainsford and Maloney 2017). In this regard Dalton (2008), in observing the negative effects of increasing levels of disengaged citizenry on the quality 
of democracy, identifies and distinguishes between four norms of 'good' citizenship. Amongst others, he refers to the development of political interest and activism of the citizen through his/her participation in political discussions with others. He posits that 'good citizens' should equip themselves with sufficient information about government to enable them to engage in political discussion and deliberation with others in a meaningful way (Dalton 2008, 79). Furthermore, he observes that these kinds of deliberations and/or discussions can influence the way in which citizens exercise their citizenship, and the impact of this behaviour on their everyday lives. Others have also emphasised the nature of discussions in how the child is socialised to politics. In the work of Saphir and Chaffee (2002) for example, reference is made to concept-orientated discussions, where communication between parents and their children involve the discussion of specific issues that relate to the environment external to the family. In their study they found that parents who were more concept-orientated initiated political discussions more frequently than those who were less concept-orientated (Saphir and Chaffee 2002, 102). Similarly, other studies illustrate the effects of parental partisanship on party identification of the child (Zuckerman, Dasovic, and Fitzgerald 2007; Kroh and Selb 2009). Albeit that traditionalists and revisionists are divided on this score, the former school of thought suggests that, in the early stages of life, the child is predisposed to political discussions where intergenerational transmission includes discussions on who parents support and vote for in particular, and what their opinions towards a particular government and/or political party are in general. Given this, not only is it important to be discussing politics in the home, but the cues transmitted through the content/nature of discussions also seem important for shaping the attitudes of the child towards government.

This brings us to focus on the trust cues transmitted within the family environment and between parents and their children. As mentioned earlier, trust is described as a necessary ingredient to the effective functioning and stability of democracies (Newton 2001; Mishler and Rose 2005; Jamil and Askvik 2016). In fact, it is identified as central to encouraging the participation of the youth in politics in future. According to Torney-Purta, Barber, and Richardson (2004, 14) 'trust in governmental institutions is a foundation upon which participation can be built'. Sztompka (1999) distinguishes between six principles of democracy that require trust. In particular he observes that trust allows for the communication of views about issues, political preferences and political support among citizens and the willingness of citizens to engage in democratic institutions and civic associations (Sztompka 1999, 147). The concept of trust is considered fundamental to all social interactions (Putnam 1993; Kim, Helgesen, and Ahn 2002; Job 2005; and Esau 2016). Regardless of its form or nature, trust is influenced by social relationships through which knowledge, experience and perceptions of an individual, institution or system is informed.

Sztompka's (1999) explanation on the foundations of trust situates the family as important to providing cues about whether to grant or withhold trust. Amongst others, he refers to reflected trustworthiness or primary trust that is predicated on the 'immanent traits of the trustee' (Sztompka 1999, 71). Essentially, reflected trustworthiness is based on the reputation, performance and appearance of the trustee. To this end, the cues provided by 
the family may be important in the context of how an individual assesses trustworthiness in the pre-adult and adult years (Sztompka 1999). Accordingly, Sztompka (1999, 73) argues,

if somebody, or some institution, is known to be trusted by others - and especially 'significant others', the people whose judgment I treat seriously - I am ready to imitate that trust, and consider the target trustworthy without considering any other cues.

Kallio (2017) also refers to the influence of cues transmitted in the family on the socialisation of the youth, but in the context of intergenerational recognition that encompasses family, institution and/or the public. She observes that 'people take shape and are shaped as political subjects' through their interaction with 'significant others' (Kallio 2017, 88). Given the importance of the testimonies of significant others, the family may provide us with reliable information about the reputation and performance of others. Therefore, and based on the aforementioned observations on the effect of parents having political discussions with their children, the trustworthy cues that parents relay to their children may affect the attitudes of trust of the youth in government.

\section{A context for examining the South Africa family environment}

Globally, the issue of trust and political interest is a concern. Dwindling trust and decreasing political engagement threaten the stability of democracies in the modern world (Rahn and Transue 1998; Putnam 2002; Van de Walle, Van Roosbroek, and Bouckaert 2008; Denemark and Niemi 2012). Denemark and Niemi (2012) refer to the effect of distrust on citizens' engagement with government, its institutions and processes. They observe that the lack of political trust, efficacy and participation erodes the link between citizens and government and hence has implications for legitimate and stable government (Denemark and Niemi 2012, 2). Moreover, they emphasise the effects of distrust on the political participation of the youth, whose social and political involvement seem to be on the decrease (Denemark and Niemi 2012). Similarly, Dalton $(2005,146)$ ) refers to the phenomenon of waning political trust of the youth in politicians and political institutions. Based on data from the American National Elections Studies, he observes that earlier generations were more likely to trust government to do the right thing (Dalton 2005, 134), in comparison to younger generations who depart from a basis of cynicism towards government.

Locally, the South African experience appears to mirror the international one, post the advent of democracy in 1994. The periods, especially between 1976 and 1990, reflected heightened political activism among different sectors of society, driven by a context of high levels of distrust of the apartheid government. Civil society organisations that included the religious sector, educators, parents and the youth mobilised against the government because of its policies of separatist development, in general, and in response to inferior education policies for black people, in particular. For example, the 1976 Soweto uprisings where students militated against oppressive education policies and laws such as the Bantu Education Act of 1953 led to violent confrontation between the police and students. Many students lost their lives on 16 June 1976 (www.sahistory.org.za/topic/ 
june-16-soweto-youth-uprising), which resulted in the emergence of nation-wide protests and demonstrations. Many other examples leading up to the dawn of democracy illustrate the high levels of political activism amongst ordinary citizens (Seidman 1994; Alexander 2010). It was precisely this kind of activism that mobilised the international world against the apartheid state. As a result, the political transition from apartheid to democracy started in the early 1990 .

In spite of achieving democracy however, not much has changed for many of the poor and marginalised. Poverty levels have increased from 27.3 million South Africans in 2011 to 30.4 million in 2015 (www.statssa.gov.za). According to Statistics South Africa's recent Labour Force Quarterly Survey, unemployment in general is high, with $27.7 \%$ of the population being unemployed, and $54 \%$ of the country's youth being unemployed (www. statssa.gov.za). Moreover, the economy is in a technical recession, with the International Monetary Fund (IMF) projecting marginal growth of $1.2 \%$ over the next year (m.fin24.com/fin24/Economy/imf-predicts-poor-growth-for-sa-20170724). In addition, the issues emerging from poor public leadership contribute to economic instability and gives rise to further concerns about trust in government and public sector institutions. For example, former president of the country Jacob Zuma, has been involved in several scandals that include allegations of corruption and sexual promiscuity. The former Public Protector, Thuli Madonsela, Pravin Gordhan, the Minister of Public Enterprises and former minister of the National Treasury, and leaders of opposition parties in South Africa, amongst others, have raised concerns about state capture. Leaders of state owned enterprises have been found guilty of mismanagement and corruption, while still others are currently on suspension, subject to further investigations.

These issues may be contributory to the trend of decreasing political interest and engagement of citizens and the youth in formal participatory state structures (Tracey 2013; Potgieter and Lutz 2014; Davids et al. 2016). According to a survey on social attitudes of South Africans, only 29\% of youth between the ages of 16-24 responded that they were interested in politics (Davids et al. 2016). Another study on the effects of the media on the identity of the South African youth, suggests low trust of the youth in public institutions, with respondents trusting local government the least (Malila et al. 2013). While the political leadership of South Africa has changed after the African National Congress's (ANC's) 54th national conference in December 2017, one cannot assume that levels of trust will increase overnight. The generation of trust is dependent on a multi-faceted process and influences at various levels and can take decades to accumulate (Putnam 1993). Therefore, in a context where the youth comprise a large proportion of the South African electorate (10.9 million eligible voters are between the ages 18-29 years), attention to the agencies that influence their political development and attitudes is essential for the survival of democracy.

\section{Methods}

This quantitative study used a cross-sectional correlational research design. This study was conducted in secondary schools in the Metro North area. The Metro North area was identified as an area of convenience to implement the study. A list of secondary schools 
was retrieved from the website of the Western Cape Education Department and this was used as a sampling frame. This list consisted of 27 schools, which were stratified according to low and high socio-economic schools, which were in close proximity to the university for students to have access for data collection. Six schools were invited to participate in the study; two identified as high, two identified as low to medium and no feepaying schools. Grade 10 learners were identified to be part of the study due to the fact that they would be eligible to vote in the next national/provincial elections in 2019. The total number of these six schools was 1109 learners. Of these six schools, only two schools participated in the study. These secondary schools were low to medium fee paying schools. The final sample consisted of 306 participants mainly being female (61.8\%), identified as Coloured (93.1\%), Afrikaans speaking (54.3\%) and living with both parents $(55.8 \%)$.

A questionnaire was used to collect the data. This instrument consisted of different sections relating to demographic information, parent-adolescent communication and trust. The questionnaire was based on an adaptation of the Afrobarometer Round 4 (with a range of statements probing the youth's views on the society that they lived in) and the Harvard study on Trust (this study explored the trust of Americans in their government), using a composite trust mean score that required respondents to indicate whether they agreed or disagreed with certain statements on trust in political office-bearers and public institutions. Participants were also probed on political communication with their parents and how comfortable they felt to discuss politics with their mothers and fathers. Participants responded on a Likert scale of $1=$ strongly agree to $4=$ strongly disagree.

Permission to conduct the study was provided by the University of the Western Cape and the Western Cape Education Department. Participants were provided with informed consent and information on voluntary participation and withdrawal. They were also informed about their confidentiality and anonymity. Once participants agreed to voluntarily participate in the study, they completed the questionnaires within group sessions. The data was analysed using SPSS resulting to determine the relational aspects of the variables.

Table 1. Mean scores and correlations of variables.

\begin{tabular}{lccccc}
\hline Variables & $N$ & Minimum & Maximum & Mean (SD) & Youth trust in government \\
\hline Parent-adolescent communication & 283 & 1.75 & 4.42 & $3.19(.45)$ & .39 \\
Family trust in government & 295 & 1.50 & 4.00 & $2.92(.53)$ & $.78^{* *}$ \\
Youth trust in government & 296 & 1.17 & 4.00 & $3.00(.61)$ & - \\
\hline
\end{tabular}

${ }^{* *}$ Correlation is significant at the 0.01 level (two-tailed).

\section{Results}

In Table 1, the prevalence of the variables is assessed. The majority of participants indicate that there are political discussions that occur between parents and their adolescents $(M=$ 3.19; $S D=.39)$. Youth $(M=3.00 ; S D=.61)$ and Family $(M=2.92 ; S D=.53)$ trust in government were almost similar with both indicating that they do not trust in 
government. Also in Table 1, a significantly positive relationship was found between family and youth trust in government $(r=.78 ; p<0.00)$. No other correlations were found between the variables.

A hierarchical regression analysis was conducted in order to determine which of the variables, family trust in government and parent-adolescent communication, predicted youth trust in government. Based on the results in Table 2, parent-adolescent communication had no effect on youth trust in government, which means that just having a conversation about political issues did not necessarily result in youth trusting in government. However, when family trust in government was added in Step 2, the full model significantly and positively predicted youth trust in government $(\beta=.77 ; p=.00)$. The final model accounted for $60 \%$ of the variance of youth trust in government.

\section{Discussion}

Based on the context of the South African youth in this study, the findings highlight the effects of the family on the political socialisation of the child in two ways. Firstly, that the family environment is a space where discussions about politics happen (Easton 1957), and that through these discussions cues are transmitted that have an effect on the attitudes that the youth have towards government. At a basic level, the political discussions happening within the family raise awareness of political life in the mind of the child (Easton 1957; Bronfenbrenner 1995, 1999). Moreover, these discussions connect the child to the political system through shaping his/her attitudes towards government, which in turn may influence whether or not the child cooperates with government and its institutions, post-childhood. In this regard, the work of Bronfenbrenner (1994) on the effects of different systems on the development of the child comes to mind. With specific reference to the political development of the child, through political discussions in the family, the interrelation between the microenvironment and the exosystem of the child is either nurtured or hampered.

Table 2. Hierarchical Regression Analysis predicting youth trust in government.

\begin{tabular}{|c|c|c|c|c|}
\hline Youth trust i|n government & $b$ & SE $b$ & $B$ & $t$ \\
\hline \multicolumn{5}{|l|}{ Step 1} \\
\hline Constant & 2.77 & & & \\
\hline Parent-adolescent communication & .08 & .08 & .06 & .93 \\
\hline \multicolumn{5}{|l|}{ Step 2} \\
\hline Constant & .34 & & & \\
\hline Parent-adolescent communication & .04 & .05 & .03 & .72 \\
\hline Family trust in government & .87 & .04 & $.77^{*}$ & 19.94 \\
\hline $\begin{array}{l}\text { In Step 1: Youth Trust in Governm } \\
\text { In Step 2: Youth Trust in Governm }\end{array}$ & & & & \\
\hline
\end{tabular}

Secondly, we can infer from the findings that a politicised family environment could either contribute to the maintenance of the political system (Easton 1957) in the case of efficient and effective public institutions, or discourage cooperation with government and its institutions. However, predisposing the child to the attitudes of the parents and/ or 
family requires more than 'general' political discussions. As reflected through the results and notwithstanding the importance attributed to political discussions as a form of socialisation (Verba, Scholzman, and Brady 1995; Jennings, Kent, and Bowers 2009; Cicognani et al. 2012), the mere act of parent-adolescent communication does not, per $s e$, influence the trust attitudes of the youth towards government, in the context of our study. While the results reflect a relationship between family trust and youth trust in government, no relationship was found between parent adolescent communication and youth trust in government. However, the results suggest that where parents discuss politics with their children and communicate their cues of trustworthiness in government, an effect on youth trust in government can be seen. In fact, parent adolescent communication and family trust in government accounted for a statistically high variance for youth trust in government.

Therefore, in the context of both the family and the youth not trusting government, we can infer that the communication of the cues of distrust could negatively affect the interrelations between the youth and government in future. In this regard, we are also reminded of Bronfenbrenner's $(1994,1995)$ proximal processes where he emphasises the nature of the interaction between the parent and the child on the latter's development. While his focus was primarily contextual, namely, the effect of socio-economic status, gender and race on human development, the content of political discussions can also be viewed as important to the proximal processes (Zuckerman, Dasovic, and Fitzgerald 2007; Kroh and Selb 2009; Jennings, Kent, and Bowers 2009; Russo and Amna 2016) that shape the attitudes of the youth towards government. Therefore, in the case of the effective transmission of cues that influence the political attitudes of the youth towards government, consideration should be given not only to the context but also the content of the interactive process within the microenvironment of the child.

\section{Conclusions and future research}

Based on our study of the South African case, the family environment is significant for the development of the political orientations of the child. It provides an initial and foundational space for discussions about politics and the transmission of cues that may influence the child's attitude towards government. However, the extent to which family attitudes influence those of the youth is dependent on the content of discussions that parents have with their children. The study shows that it is not sufficient to have discussions about politics in general, but that these discussions should be about specific issues or concepts, if the family environment is to have an effect on the nature of the interrelation between the youth and the political system. Therefore, given the concerns about waning political interest and dwindling trust of the youth in government and its institutions, the family environment is important for encouraging the interest of the youth in politics and shaping their attitudes towards government. Where the transmission of attitudes emphasise cooperative relations between the state and its citizens, the agency of family preserves the traditions of democracy. However, where negative attitudes, beliefs and values about government are transmitted within the family, youth may become disheartened, politically 
apathetic and disengage from political life. To this end, the microenvironment of the family may contribute to antagonistic interrelations between the youth and the political system.

In summary, families are talking about politics, have certain trust predispositions towards government and where these are communicated, may influence the predispositions of their children towards government. In this way they are contributing to the political learning of their children, which in turn may influence how the latter behaves within the political sphere in future. Considering that trust is a precondition for cooperative relations between government and citizens, and that the family is transmitting trust cues through their discussions with their children, the direction of these cues can affect the traditions of democracy. Within an emerging democratic context such as that of South Africa, the disengagement of citizens in general, and the youth in particular, can affect the development of ideal-type democratic practices, norms and values. These findings suggest that the family is an agency of political socialisation within the context of South Africa. Therefore, efforts should be made to augment what is happening in the space of the family environment, be it through the educational sector, civil society or government departments, as a means of further stimulating and developing the political consciousness and activism of the youth.

This study provided an exploratory lens through which to examine the effect of the family on the political socialisation of the child in an emerging democratic context. To this end, its focus was limited to examining the prevalence and effects of political discussions and family attitudes of trust on youth trust in government. The study was further limited to the perspectives and experiences of the youth. Therefore, in the light of the findings that the family environment is a conduit between the child and the political system, future research could examine the longer-term effects of both family attitudes and behaviours across the life span of an individual. Such a study could include both parents and children and take into consideration issues of political knowledge, socio-economic status and gender. These variables may provide interesting insights that facilitate our understanding of the role of the family in the politicisation of the child within emerging democracies.

\section{Acknowledgements}

The authors wish to acknowledge the seed funding provided by the University of the Western Cape that enabled the data collection at the various schools under study.

\section{Disclosure statement}

No potential conflict of interest was reported by the authors.

\section{Funding}

This work was supported by University of the Western Cape: [Grant Number 15/7/216].

\section{ORCID}

Nicolette Vanessa Roman http://orcid.org/0000-0002-4506-437X 


\section{References}

Alexander, Peter. 2010. "Rebellion of the Poor: South Africa's Service Delivery Protests - A Preliminary Analysis." Review of African Political Economy 37 (123): 25-40.

Amna, Erik, Mats Ekstrom, Margaret Kerr, and Hakan Stattin. 2009. "Political Socialization and Human Agency: The Development of Civic Engagement From Adolescence to Adulthood." Statsvetenskaplig Tidskrift 111 (1): 27-40.

Andolina, Molly, Krista Jenkins, Cliff Zukin, and Scott Keeter. 2003. "Habits From Home, Lessons From School: Influences on Youth Civic Engagement." Political Science and Politics 36 (2): 275-280.

Beck, Paul, and M. Kent Jennings. 1991. "Family Traditions, Political Periods, and the Development of Partisan Orientations." The Journal of Politics 53 (3): 742-763.

Bessant, Judith. 2004. "Mixed Messages: Youth Participation and Democratic Practice." Australian Journal of Political Science 39 (2): 387-404.

Bronfenbrenner, Urie. 1994. "Ecological Models of Development." In International Encyclopedia of Education, edited by T. Husen, and N. Postlethwaite, 1643-1647. Oxford: Elsevier.

Bronfenbrenner, Urie. 1995. "Developmental Ecology Through Time and Space: A Developmental Perspective." In Examining Lives in Context: Examining Perspectives on the Ecology on Human Development, edited by P. Moen, G. H. Elder, Jr. and K. Luscher, 619-647. Washington, DC: American Psychological Association.

Bronfenbrenner, Urie. 1999. "Environments in Developmental Perspective: Theoretical and Operational Models.” In Measuring Environments Across the Life Span: Emerging Methods and Concepts, edited by T. D. Wachs, 3-28. Washington, DC: American Psychological Press.

Cicognani, Elvira, Zani Bruno, Fournier Bernard, Claire Gavray, and Michel Born. 2012. "Gender Differences in Youths' Political Engagement and Participation. The Role of Parents and of Adolescents' Social and Civic Participation." Journal of Adolescence 35 (3): 561-576.

Coffe, Hilde, and Marieke Voorpostel. 2010. "Young People, Parents and Radical Right Voting. The Case of the Swiss People's Party." Electoral Studies 29 (3): 435-443.

Crystal, David S., and Matthew DeBell. 2002. "Sources of Civic Orientation Among American Youth: Trust, Religiious Valuation, and Attributions of Responsibility." Political Psychology 23 (1): 113-132.

Dalton, Russell. 2005. "The Social Transformation of Trust in Government." International Review of Sociology 15 (1): 133-154.

Dalton, Russell. 2008. "Citizenship Norms and the Expansion of Political Participation." Political Studies 56 (1): 76-98.

Davids, Yul, Tyanai Masiya, Jare Struwig, Steven Gordan, and Benjamin Roberts. 2016. Youth interest and understanding in South African politics. www.hsrc.ac.za/en/media-briefs/democracy...and.../youth-understanding-sa-politics.

Denemark, David, and Richard Niemi. 2012. "Political Trust, Efficacy and Engagement in Challenging Times: An Introduction.” Australian Journal of Political Science 47 (1): $1-9$. 
Dinas, Elias. 2014. "Why Does the Apple Fall Far From the Tree? How Early Political Socialization Prompts Parent-Child Dissimilarity." British Journal of Political Science 44 (4): 827-852.

Easton, David. 1957. "An Approach to the Analysis of Political Systems." World Politics. 9: 383-40o. Cambridge: Cambridge University Press.

Easton, David, and Jack Dennis. 1965. "The Child's Image of Government." The Annals of the American Academy of Political and Social Science 361 (1): 40-57.

Errante, Antoinette. 1999. "Peace Work as Grief Work in Mozambique and South Africa: Postconflict Communities as Context for Child and Youth Socialization." Peace and Conflict: Journal of Peace Psychology 5 (3): 261-279.

Esau, Michelle. 2016. "Exploring Institutional Trust and Organizational Performance Through the Case of the City of Cape Town." International Journal of Public Administration 39 (9): 686-693.

Esau, Michelle, and Nicolette Roman. 2015. "Political Socialization of the Youth: An Examination of the Family as an Agency for Youth Citizenship in South Africa." In Parenting: Behaviours, Cultural Influences and Impact on Childhood Health and Well-Being, edited by N. V. Roman, 39-54. New York: Nova Science Publisher, Inc.

Finkel, Steven, and Howard Ernst. 2005. "Civic Education in Post-Apartheid South Africa: Alternative Paths to the Development of Political Knowledge and Democratic Values." Political Psychology 26 (3): 333-364.

Gelles, Richard. 1995. Contemporary Families: A Sociological View. Thousand Oaks, CA: Sage. Hampton, Keith N., Inyoung Shin, and Weixu Lu. 2017. "Social Media and Political Discussion: When

Online Presence Silences Offline Conversation." Information, Communication and Society 20 (7): 1090-1107.

Hyman, Herbert. 1959. Political Socialization. Glencoe IL: The Free Press.

Jamil, Ishtiaq, and Steinar Askvik. 2016. "Introduction to the Special Issue." International Journal of Public Administration 39: 647-651.

Jennings, M., Laura Stoker Kent, and Jake Bowers. 2009. "Politics Across Generations: Family Transmission Reexamined." The Journal of Politics 71 (3): 782-799.

Job, Jenny. 2005. "How is Trust in Government Created? It Begins at Home, but Ends in the Parliament." Australian Review of Public Affairs 6 (1): 1-23.

Kallio, Kirsi Paulina. 2014. "Rethinking Spatial Socialisation as a Dynamic and Relational Process of Political Becoming." Global Studies of Childhood 4 (3): 210-223.

Kallio, Kirsi Paulina. 2017. "Shaping Subjects in Everyday Encounters: Intergenerational Recognition in Intersubjective Socialisation.” Society and Space 35 (1): 88-106.

Kim, Uichol, Geir Helgesen, and Byung Man Ahn. 2002. "Democracy, Trust and Political Efficacy: Comparative Analysis of Danish and Korean Political Culture." Applied Psychology 51 (2): 318-353.

King, Gary, and Richard M Merelman. 1986. "The Development Of Political Activists: Toward A Model Of Early Leaning." Social Science Quarterly 67 (3): 473-490.

Kristensen, Niels N., and Trond Solhaug. 2017. "Party Choice and Family Influence in the Age of Late Modernity - Students' Reflections as First-time Voters in a Norwegian 
Parliamentary Election.” Journal of Humanities and Social Science Education 4: 4869.

Kroh, Martin, and Peter Selb. 2009. "Inheritance and the Dynamics of Party Identification." Political Behavior 31 (4): 559-574.

Lee, Nam-Jin, Dhavan V. Shah, and Jack M. McLeod. 2012. "Processes of Political Socialization: A Communication Mediation Approach to Youth Civic Engagement." Communication Research 40 (5): 669-697.

Malila, Vanessa, Jane Duncan, Irene Costera Meijer, Nico Drok, Anthea Garman, Larry Strelitz, Lynette Steenveld, Tanja Bosch, Musa Ndlovu, and Media Tenor. 2013. A Baseline Study of Youth, Identity, the Media and the Public Sphere in South Africa. Grahamstown: Rhodes University.

Mattes, Robert, and Samantha Richmond. 2014. South Africa's Youth and Political Participation, 1994 - 2014. Working Paper. No. 338. Cape Town: Centre for Social Sciences Research.

McIntosh, Hugh, Daniel Hart, and James Youniss. 2007. "The Influence of Family Political Discussion on Youth Civic Development: Which Parent Qualities Matter?.” Political Science and Politics 40 (3): 495-499.

Mishler, William, and Richard Rose. 2005. "What Are the Political Consequences of Trust?.” Comparative Political Studies 38 (9): 1050-1078.

Newton, Kenneth. 2001. "Trust, Social Capital, Civil Society and Democracy." International Political Science Review 22 (2): 201-214.

Niemi, Richard G., and Barbara I. Sobieszek. 1977. "Political Socialization." Annual Review of Sociology 3: 209-233.

Paquette, Dede, and John Ryan. 2011. Bronfenbrenner's Ecological Systems Theory. http://pt3.n1.edu/ paquetteryanwebquest.pdf.

Potgieter, Elnari, and Barend F. Lutz. 2014. 'South African Youth: Politically Apathetic? Election Update South 2014. https://www.eisa.org.za/eu/2014eugeditorial2.htm.

Putnam, Robert D. 1993. Making Democracy Work: Civic Traditions in Modern Italy. New Jersey: Princeton University Press.

Putnam, Robert D. 2002. Democracies in Flux: The Evolution of Social Capital in Contemporary Society. New York: Oxford University Press.

Quintelier, Ellen. 2013. "Engaging Adolescents in Politics." Youth and Society 47 (1): 51-69.

Quintelier, Ellen. 2015. "Intergenerational Transmission of Political Participation Intention." Acta Politica 50 (3): 279-296.

Rahn, Wendy M., and John E. Transue. 1998. "Social Trust and Value Change: The Decline of Social Capital in American Youth, 1976-1995." Political Psychology 19 (3): 545565 .

Rainsford, Emily, and William Maloney. 2017. Family Matters: The Intergenerational Transmission of Social Capital. Unpublished paper. Paper presented at political studies association conference, Glasgow, April. blogs/se.ac.uk.

Russo, Silvia, and Erik Amna. 2016. "When Political Talk Translates Into Political Action: The Role of Personality Traits." Personality and Individual Differences 100: 126-130. 
Saphir, Melissa, and Steven Chaffee. 2002. "Adolescents' Contributions to Family Communication Patterns." Human Communication Research 28 (1): 86-108.

Schoon, Ingrid, and Helen Cheng. 2011. "Determinants of Political Trust: A Lifetime Learning Model." Developmental Psychology 47 (3): 619-631.

Seidman, Gay W. 1994. Manufacturing Militance: Workers' Movements in Brazil and South Africa, 1970- 1985. Berkley: University of California Press.

Stoker, Gerry. 2017. Why Politics Matters: Making Democracy Work. 2nd ed. London: Palgrave MacMillan.

Sztompka, Piotr. 1999. Trust: A Sociological Theory. Cambridge: Cambridge University Press.

Torney-Purta, Judith, Carolyn Henry Barber, and Wendy Klandl Richardson. 2004. "Trust in Government-Related Institutions and Political Engagement among Adolescents in Six Countries." Acta Politica 39 (4): 380-406.

Tracey, Lauren. 2013. What Can Be Expected From Young Voters in South Africa's 2014 Elections? https:// issafrica.org/ ... /what-can-be-expected-from-young-voters-insouth-africas-2014-Elections?

Van de Walle, Steven, Steven Van Roosbroek, and Geert Bouckaert. 2008. "Trust in the Public Sector: is There any Evidence for a Long-Term Decline?." International Review of Administrative Sciences 74 (1): 47-64.

Verba, Sidney, Kay Lehman Scholzman, and Henry E. Brady. 1995. Voice and Equality: Civic Voluntarism in American Politics. London: Harvard University Press.

Watts, Roderick J., and Constance Flanagan. 2007. "Pushing the Envelope on Youth Civic Engagement: A Developmental and Liberation Psychology Perspective.” Journal of Community Psychology 35: 779-792.

Zeldin, Shepherd, Josset Gauley, Steven Eric Krauss, Mariah Kornbluh, and Jessica Collura. 2017. "Youth-Adult Partnership and Youth Civic Development: CrossNational Analyses for Scholars and Field Professionals.” Youth and Society 49 (7): 851-878.

Zuckerman, Allan S., Josip Dasovic, and Jennifer Fitzgerald. 2007. Partisan Families: The Social Logic of Bounded Partisanship. Cambridge: Cambridge University Press. 